International Journal of Instruction e-ISSN: 1308-1470 • www.e-iji.net

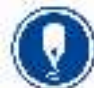

Article submission code: 20200728170739
Received: 28/07/2020

Revision: 25/01/2021
July $2021 \bullet$ Vol.14, No.3

p-ISSN: 1694-609X

pp. $807-826$

Accepted: 17/02/2021

OnlineFirst: 19/06/2021

\title{
Distance learning practices on the Example of Second Language Learning during Coronavirus Epidemic in Russia
}

\section{Ekaterina Nenakhova}

The National Research South Ural State University, Russia, Nenakhovaea@susu.ru

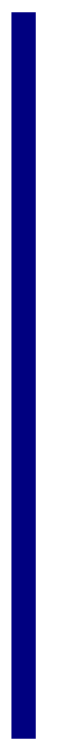

The CoronaVirus (COVID19) made the higher education establishment take on urgent measures when all the students were prohibited from entering the university not to catch the disease, but the educational process was not to be stopped. Distance education tools were to be applied and digital platforms of the universities were to be checked. This paper deals with the experience of the National Research South Ural University. The courses of all the schools and institutes of the University were conducted based on the platform Digital SUSU. The example of the courses for second language learning was discussed. Fifty students of bachelor's and master's degrees were respondents in this research. The students answered the questions of the questionnaire on Google Forms and then were interviewed. The results suggest that the most interesting task on the planform Digital SUSU was a video with tasks and vocabulary exercises. However, among the most useful, according to the students' opinion were grammar, vocabulary, and reading tasks. The students were also asked to discuss the advantages and disadvantages of such remote learning. The most frequently mentioned advantages were the ability to study at home and the absence of the necessity to look smart. However, the disadvantages were more varied, including absence of communication, no face to face contact, too much homework, and too many written tasks.

Keywords: The CoronaVirus (COVID19), distance learning, remote teaching, foreign language teaching, distance course creation

\section{INTRODUCTION}

Higher institutions in Russia have been promoting the idea of distance education for several years. It all started with correspondence education, which provided people in remote regions of Russia with the ability to get higher education without having to move to the centers with universities or spend much money in the 19th century. Technologies brought about the possibility to participate in classes online and get responses immediately, as mail corresponding was usually delayed and could even be lost.

However, the idea of completely shifting higher education programs into distance learning platforms seems rather doubtful now. The authors identify both benefits of

Citation: Nenakhova, E. (2021). Distance learning practices on the example of second language learning during coronavirus epidemic in Russia. International Journal of Instruction, 14(3), 807-826. https://doi.org/10.29333/iji.2021.14347a 
distance education such as solution for lack of educational space (Bollag, B., \& Overland M.A. (2001)), the achievement of "deeper levels of knowledge generation through the creation of shared goals, shared exploration, and a shared process of meaning making" (Palloff and Pratt (2000)), higher education becoming more costeffective (Dibiase, 2000), client oriented approach in higher educational establishments (Alekseev, V., Ilchenko, S., 2016), Twigg (2002) described the e-learning approach as centered on the learner as well as its design as involving a system that is interactive, repetitious, self-paced, and customizable. However, the disadvantages can include the following points: only specific collective assessment is improved (Dowling et al. (2003)), "complete absence of vital personal interactions, not only between learners and instructors but also among colleague learners" (Young, 1997; Burdman, 1998), quality of teaching may suffer due to the problems with the technical issue of distance learning.

The CoronaVirus (COVID19) outbreak in December 2019, which the World Health Organization (WHO) classified COVID19 as a global pandemic in March 2020 (WHO, 2020), upset the plans of the whole world. To stop the pandemic tendency, the governments had to adopt restrictions aimed at limiting any contacts of people. Thus, the closure of educational establishments was just a matter of time. It is reported that more than 1.5 billion learners of all ages from around the globe are affected due to school and university closures owing to the COVID-19 (UNESCO, 2020a; UNICEF, 2020).

However, there arose a reasonable question of how to avoid problems both academic and financial, connected with interruption of the educational process, as many students could fall behind with the programme and therefore doubt the legitimacy of payment taken for the whole year of study. Consequently, the issue of implementing distance education on a global scale came forward.

Bozkurt, A., \& Sharma, R. C. (2020) state that "there is no magic spell to make things right, and it is a well-known fact that the one size fits all understanding does not work anymore". A lot of issues should be considered and taken into consideration, including but not limited to the social and economic context.

However, such a sudden and unexpected shift from university ground to home place cannot be considered a distance education in its full meaning. The authors argue that here we deal with emergency remote education/ learning/ teaching. Thus, "with some nuances of implementation in remote teaching (Turoff, \& Hiltz, 1986), distance education slightly differs from emergency remote teaching". Bozkurt, A., \& Sharma, R. C. (2020) points out that although both distance and remote education "has served well in responding to learning needs and in guiding open educational practices", distance education is more about distance in "time and/or space between learners and learning resources", whereas remote education "refers to spatial distance". In what concerns the aims and goals, distance education is applied to let learners be more engaged in the learning process (Moore, 1989; Riggs, 2020). In case with remote teaching, no alternative promotes searching for alternatives enabling some kind of personal interaction. In this sense, online distance education and emergency remote teaching are not the same things. Bozkurt, A., \& Sharma, R. C. (2020) warn against rushing into 
emergency remote teaching," calling it online distance education or online learning and assuming online tools to be a form of online distance education", as it can lead to mistakes, which, once things are "settled and go back to normal", people will remember as "bad examples from a time of crisis". Having said that, it is vital to choose strategies and tools carefully, while applying remote teaching using the best from distance learning techniques.

Bozkurt, A., \& Sharma, R. C. (2020) indicate that "when we consider online distance education, we should go beyond sharing simple tools, tips, and tricks and instead focus on the changing learners' needs, learning contexts, and the availability and accessibility of the tools". Moreover, it should be remembered that whereas distance education is "an alternative and flexible option for learners, emergency remote teaching is an obligation, which means that we have to use different strategies and approach the case with different priorities".

The paper deals with the experience of online distance learning while applying distance learning tools at National Research University Chelyabinsk Russia. The experience appears to be positives in general.

Foreign language courses (English language) will be presented as an example. Foreign language appears to be a very vivid example. Hismanoglu, M. (2012) in his paper cites other authors such as Lafford and Lafford (1997), Lee (2000); Alvine (2000); Lee (2003), stating that the field of foreign language learning has always been pioneering in using digital technologies, namely online chat-room, web-based course programs and, publishing project work. In this research, the course is allocated on the platform Digital SUSU, which integrates Moodle technology, forum, and BBB (BigBlueButton).

\section{SUSU before The Corona virus.}

The National Research South Ural State University is one of the greatest universities in the Russian Federation. In 2013 the University became the participant of Project 5-100, which is the state programme aimed at supporting the leading Russian institutions of higher education. The main purposes of this state programme include increasing the competitiveness of the Russian education in the world educational and research area by 2020. As a result, the university is to enter the academic ratings such as Quacquarelli Symonds, Times Higher Education, and Academic Ranking of World Universities.

South Ural State University described the programme development in the road map, where they indicated the main goal, which was to transform the university into SMARTuniversity. The platform Digital SUSU facilitated both academic and educational performance of the teaching staff and students. This system was implemented 10 years ago. Its initial aim was to enable fully-fledged distance education in the Institute of Open and Distance Education, which has been working since 2004. After delivering case technologies, conducting correspondence education with the help of mail service, the Digital SUSU platform allowed conducting online distance education. 
System of the digital education Moodle - the most popular and freely shared system for conducting distance education - forms the basis of the platform. It was easily implemented as the source code of the system is open.

This paper aims to consider the peculiarities of foreign language teaching that's why all the examples will be connected with this subject.

Before The CoronaVirus (COVID19) outbreak in Chelyabinsk, the platform Digital SUSU was successfully implemented as a source of additional listening, vocabulary, and grammar practices, usually for those students who fall behind both because of viable reasons and not (cutting classes intentionally). Later, this platform was used for creating courses for each subject with the specified control points students had to cover to get a passing point according to the point rating system, being introduced in SUSU at that time.

However, that system and the courses were only considered as a blended learning aspect. Yet, each group was enrolled in a course, so the basis for emergency remote teaching was laid.

In March it became obvious that seasonal flu was on the rise and the university considered the opportunity to stop onsite learning, but for the sake of keeping up with the education program, it was decided to brush up the courses and add the required content - online lectures, practice tasks to the courses. So, the quarantine measures were postponed.

However, on the $30^{\text {th }}$ of April SUSU started emergent remote teaching. The material was added, so we managed to overcome the stress, and yet, we hoped for soon returning to the classroom. With time being, it became clear that the pandemic situation will continue as numbers of those infected with The Corona Virus rocketed in Chelyabinsk.

\section{Local peculiarities of SUSU experience}

The possibility of face-to-face communication quite necessary for foreign language acquisition was realized with the help of the video conference system BigBlueButton (BBB). It implements the core web conferencing features under an open source license. These core features include audio/video sharing, presentations with extended whiteboard capabilities - such as a pointer, zooming and drawing - public and private chat, breakout rooms, screen sharing, integrated VoIP using Free SWITCH, and support for the presentation of PDF documents and Microsoft Office documents.

In the conditions of South Ural State University, BBB facilitated online communication both with camera and without it. As BBB was integrated into the platform Digital SUSU and enabled recording a lesson or any part of it, it was a good instrument for controlling both the students and the staff to the extent that they stick to the timetable and the procedures approved by the guidance department.

The teachers worked according to the timetable, so much production efficiency was required from SUSU servers. Nowadays, during these nationwide closures, there are 
more than 5500 courses on the platform Digital SUSU with over 28000 registered incampus users.

The department of SUSU IT development is connected to Google services for education. They correlated login services with SUSU systems so that all the teachers could use unlimited opportunities of Google cloud service. Moreover, to make the situation more common for students, the teachers were allowed to use other social networking sites and game planforms as Vkontakte, Discord, Zoom, Viber, Google Meet.

Both the staff and the students experienced advantages and disadvantages of such a form of distance learning. Attendance of lessons increased, foreign students who had to leave home due to the pandemic situation could participate in the learning process, teachers could maintain the same work load, thus preventing falling behind the educational program, students could easily reach the teacher if they had questions. However, most of the staff complained of work load increase connected with the necessity to prepare tasks in the Moodle system, which requires some technical knowledge as well.

However, Despotović-Zrakić, M., Marković, A., Bogdanović, Z., Barać, D., \& Krčo, S. (2012) state that in most cases, Moodle "LMS users belong to heterogeneous groups with different individual, sometimes even adverse, characteristics and needs. The adaptation of e-education systems to an individual or a group based on their characteristics, expectations, knowledge, and preferences of the students" is required to make the system more tailored to the special needs of users. There are some aspects of higher education which distance learning cannot provide.

Rector of the SUSU Shestakov approved the procedural rules of conducting lessons in remote regime. All the teachers had to follow the unified form of the procedure description, announcement form on the course page.

English language lesson in the traditional model of onsite teaching is conducted using original learning aids in paper or electronic form. The same procedure was preserved in time of pandemic restrictions but the arose some necessary additions.

\section{Significance of the study}

The current research is significant as the 2020 pandemic situation showed that traditional classroom work can be challenged by unexpected circumstances and difficult times can require quick and effective measures as the period of some challenging situations may go beyond all expectations. To maintain the achieved knowledge and to fulfil the academic programme fully, a distance course should both support a more traditional blended learning class or be self-standing one in case of the situation when remote teaching is required. Therefore, the current research will examine the existing course on the platform Digital SUSU and the results of the questionnaire and the interview which were conducted among the students who studied during the Corona Virus pandemic from March to June 2020. 


\section{Courses description and their peculiarities}

The courses differed according to the student books used in this group, their major, number of lessons per week, and year of study. But generally, each lesson contained all the aspects of foreign language skill formation required for the successful acquisition of a second language.

The paper assesses how different aspects of a lesson can be presented and the attitude of students to the activities and the form of their presentation and control.

Table 1 presents the content of lessons by aspects.

Table 1

Content of lessons on Digital SUSU platform

\begin{tabular}{|c|c|c|c|}
\hline Aspect & Content & Types & Frequency \\
\hline $\begin{array}{l}\text { Vocabulary } \\
\text { check up }\end{array}$ & Interactive exercises & $\begin{array}{l}\text { 1. Match the word with its definition } \\
\text { 2. Match the word with its translation } \\
\text { 3. Match the word with the picture } \\
\text { 4. Fill in the blank with suitable word. } \\
\text { 5. Drop and drag the word into text or sentence }\end{array}$ & Every lesson \\
\hline $\begin{array}{l}\text { Grammar } \\
\text { check up }\end{array}$ & Interactive exercises & $\begin{array}{l}\text { 1.Graphical or visual representation of grammar } \\
\text { rules. } \\
\text { 2. Choose the correct form } \\
\text { 3. Fill in the blanks with the correct tense }\end{array}$ & Every lesson \\
\hline Reading & $\begin{array}{l}\text { Interactive exercises } \\
\text { Attached texts }\end{array}$ & $\begin{array}{l}\text { 1. Answer the question } \\
\text { 2. Mark the sentences TRUE or FALSE } \\
\text { 3. Fill in the blanks with the missing sentence } \\
\text { 4. Match the title to the paragraph }\end{array}$ & Every lesson \\
\hline $\begin{array}{l}\text { Listening/ } \\
\text { Video }\end{array}$ & $\begin{array}{l}\text { Interactive exercises } \\
\text { Attached mp3 files } \\
\text { URL links }\end{array}$ & $\begin{array}{l}\text { 1. Fill in the blank with suitable word. } \\
\text { 2. Drop and drag the word into text or sentence } \\
\text { 3. Answer the question } \\
\text { 2. Mark the sentences TRUE or FALSE }\end{array}$ & Every lesson \\
\hline Writing & $\begin{array}{l}\text { Task with } \\
\text { attachment } \\
\text { possibility }\end{array}$ & $\begin{array}{l}\text { 1. Write an essay (on the topic connected with } \\
\text { the unit being covered) }\end{array}$ & $\begin{array}{l}\text { Aa a check } \\
\text { point }(3-5 \\
\text { times a term) }\end{array}$ \\
\hline
\end{tabular}

The tasks on the platform Digital SUSU were interactive, they were assessed automatically. The tasks were formed in Moodle patterns. The examples of the tasks are presented in Appendix A.

\section{METHOD}

The study was conducted with 50 participants, who had 5 or 6 hours of English lessons a week. These are the groups, which participate in the experiment of the advanced language study under Project 5-100. The obligatory English language programme lasts for two years in case with a bachelor's degree and for one year at a master's degree, authentic teaching materials are used. The outcome of the programme is international exams: KET, PET (internal Mock exams) FCE, and IELTS (certificates from authorized agencies). The students are divided according to the CERF levels. The students who participated in the survey were of levels A2, B1, and B2. 
The survey consisted of a questionnaire and an interview. Due to ethical considerations, the questionnaire was anonymous, whereas the interview was personalized; however, the students were told that this research would not be used for any assessment purposes and that personal details would be kept confidential.

According to Cohen (2013), a questionnaire is an instrument for collecting the primary data, whereas Cresswell (2012) states that an interview is typically a face-to-face conversation between a researcher and a participant, used for uncovering the story behind a participant's experiences and pursuing in-depth information around a topic'. For the current research, both an interview and a questionnaire were used as it was intended to get the students' feedback about the task in the courses they liked more and then get their personal opinion concerning the advantages and disadvantages of remote teaching on the whole and the attitude to the foreign language course in particular.

I stage - Questionnaire.

The courses were constructed based on the topics, grammar, and vocabulary of the teaching materials being used in the traditional study process (Touchstone 2, English file upper-intermediate, English for bachelors of Economics), but the main components were similar and are shown in Table 1 above.

The questions were to determine what form of remote teaching they preferred and what forms of activities appealed to them most. All the suggested forms were stipulated by the procedure approved by the rector's office and the guidance department. The questions were closed as the two-stage experiment was used. The first stage was to assess the methods, forms, and strategies used during the remote learning in the Corona Virus pandemic situation. The advantages and disadvantages of remote learning were taken from the literature dealing with distance learning or from oral commentaries received from the students.

The following questions were included in the questionnaire which was presented in Google Form.

\section{What form of work did you prefer more?}

- Forum; - Written task without contact with the teacher; - BBB (BigBlueButton) without camera; - BBB (BigBlueButton) with camera; - Other resources like Google meet or Discord

\section{When did you prefer to study?}

- During lessons; - When it is suitable for me

3. What form of interactive exercises did you find more interesting?

- Video; - Grammar; - Vocabulary; - Reading; - Writing

4. What form of exercise did you find the most useful?

- Video; - Grammar; - Vocabulary; - Reading; - Writing 
5. What advantages of distance learning education do you agree with?

- Reliable; - Anonymous; - Interactive; - Possibility to study from home; - Flexible

- No face to face contact; - It does not matter how you look during your lesson

6. What disadvantages of distance learning do you agree with?

- Technical requirements; - No face to face contact; - Lack of communication

- Too much individual work; - Too many written tasks

II stage - Interview.

The students were asked to give feedback on the advantages and disadvantages of their experience of distance learning in the conditions of remote teaching. The purpose of the interview was to extend the suggested options and to get a deeper understanding of the situation.

\section{FINDINGS}

The results of the questionnaire are presented in the form of bar charts and tables.

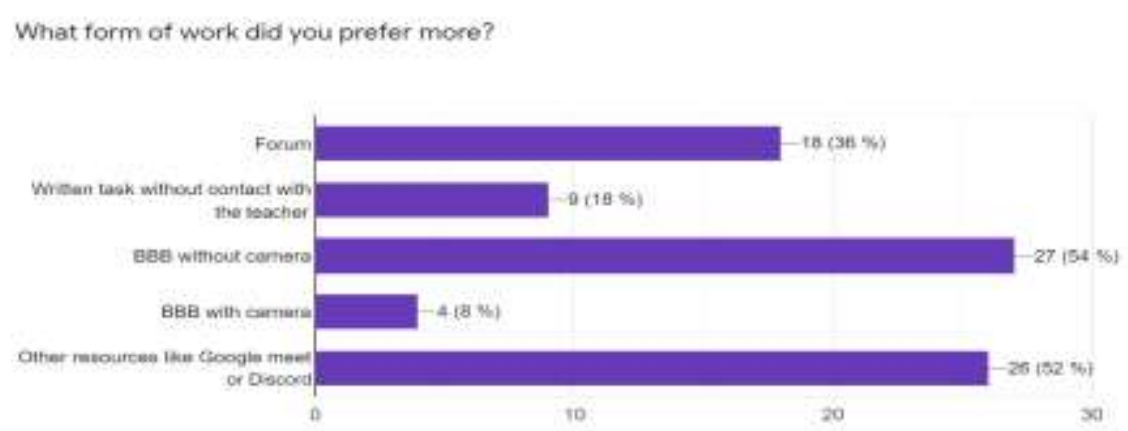

Table 1

Preferable type of lecture delivery

The results show that the most preferable form of delivering a lesson is BBB (BigBlueButton) without a camera - 54\% (27 participants), whereas other resources such as Google Meet or Discord are of the same convenience, mostly Discord as it is a proprietary freeware instant messaging and VoIP application and digital distribution platform designed for creating communities ranging from gamers to education and businesses. Discord specializes in text, image, video, and audio communication between users in a chat channel. Discord runs on Windows, macOS, Android, iOS, Linux, and in web browsers. The students preferred Discord as they knew how to operate it before the pandemic changed the conditions of the study process and it had simpler technical requirements compared to $\mathrm{BBB}$. 
Forums and written tasks required even less contact with the teacher and other students, so they had rather high values as well: $36 \%$ (18 participants) and 18\% (9 participants) respectively.

The least preferred form appeared to be BBB with a camera $-8 \%$ (4 participants). Visual contact seems to be the least favoured form of learning, both due to technical obstacles (video conferencing is more sensitive to the quality of internet connection) and the necessity to let other people see your private life.

When did you prefer to study?

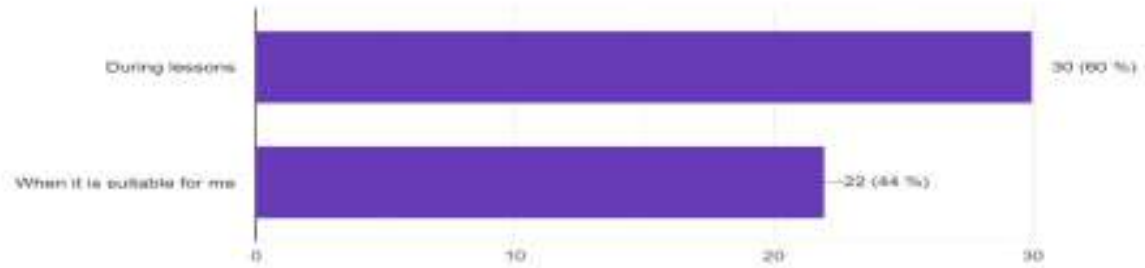

Figure 2

Preferred study time

Understanding the challenges, the students can have with the Internet availability some of the approved tasks allowed for some delay with fulfilling the tasks. However, still doing the tasks during the lessons is favoured more by the students - 60\% (30 participants), whereas rather a large number of students prefer to postpone doing the task till more suitable time $-44 \%$ ( 22 people). The uneven results suggest that some recipients were not sure and chose both options.

What form of interactive exercises did you find mone interesting?

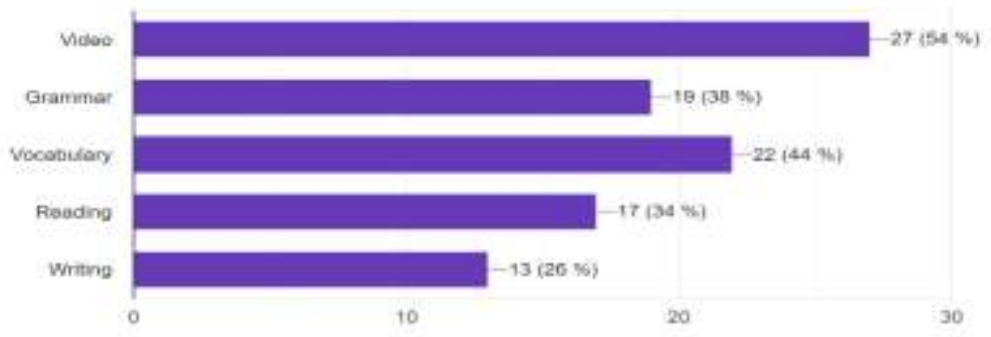

Figure 3

Favoured types of interactive exercises

Tasks on the platform Digital SUSU were mostly to train listening skills and to motivate engagement entertainingly. So, they were the most preferred ones - 54\% (27 participants). Vocabulary tasks were the second most favoured $-44 \%$ (22 participants). Writing tasks, which were the most time consuming and requiring the majority of skill, were the least interesting for the students $-26 \%$ (13 participants) 
What form of exercise did you find the most useful?

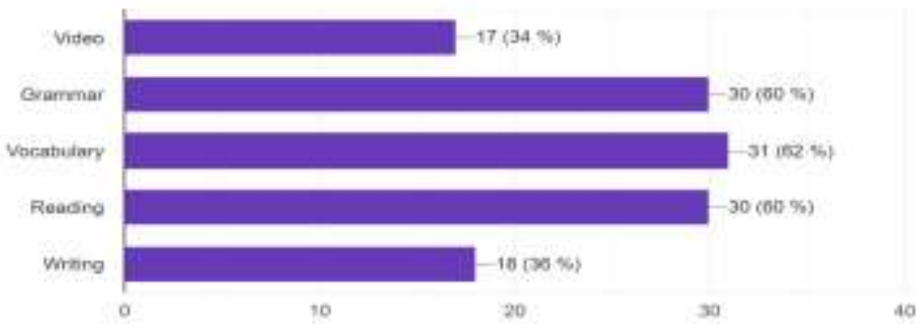

Figure 4

The most useful types of interactive exercises

The most useful tasks turned out to be on vocabulary - 62\% (31 participants), grammar $-60 \%$ (30 participants), and reading ones $-60 \%$ (30 participants). Although video tasks are considered to be the most interesting, they were found to be the least useful $-34 \%$ (17 participants), while the basic skills: grammar, vocabulary, and reading were marked as the most useful.

\section{What advantages of distance learning education do you agree with?}

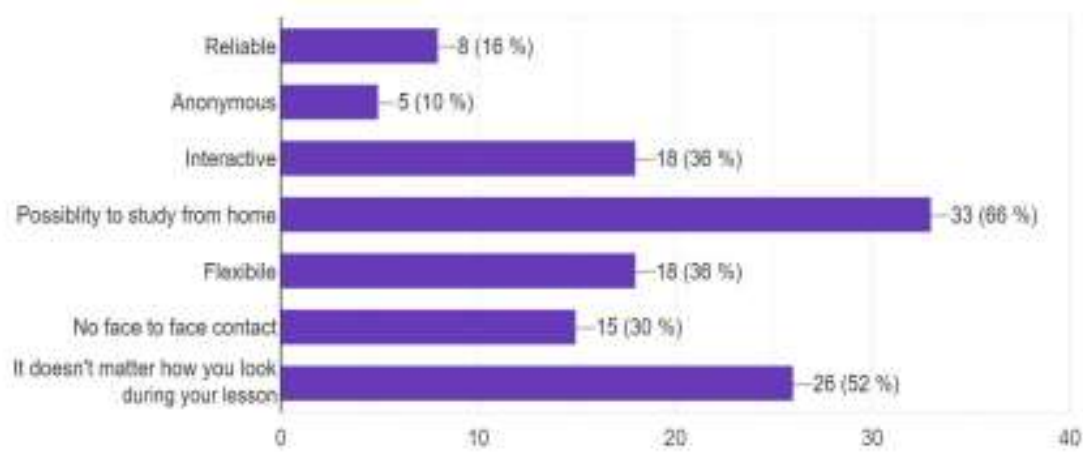

Figure 5

Advantages of distance learning

Possibility to study from home is viewed as the greatest advantage of this form of distance education - 66\% (33 participants), as well as the absence of necessity to look smart $-52 \%$ (26 participants). The fact that remote learning is interactive and flexible was agreed upon by $36 \%$ (18 participants). No face to face contact is considered more as a disadvantage $-36 \%$ (18 participants) than an advantage $-30 \%$ (15 participants). The recipients found reliability $-16 \%$ (8 participants) and anonymity $-10 \%$ (5 participants) to be the least advantages of remote learning. 
What disadvantages of distance learning do you agree with?

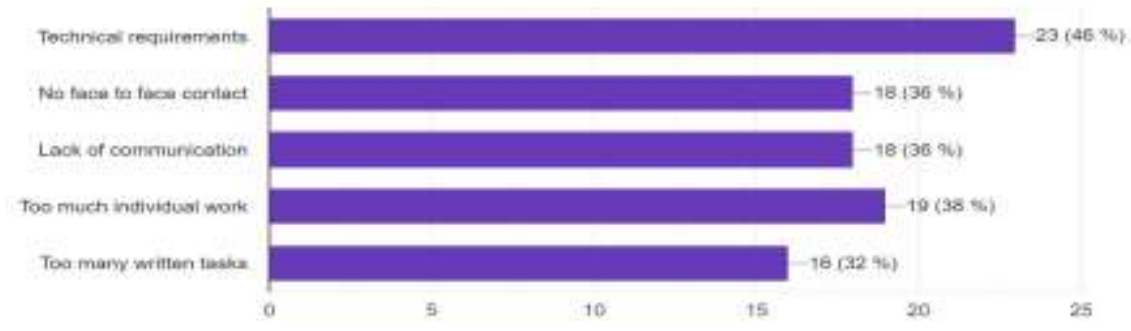

Figure 6

Disadvantages of distance learning

The greatest disadvantage is technical requirements $-46 \%$ (23 participants). The fact that the whole country had to start distant or remote studying, teaching, working, made it impossible for some families to provide all the members with technical devices fully equipped with a camera, microphone, and high-speed internet connection.

The great load of work has always been a least favourable issue for some Russian students, so the fact that 36\% (19 participants) of the students chose "too much individual work" and 32\% (16 participants) chose "too many written tasks" seems quite explainable. Lack of communication and no face to face contact are found to be a disadvantage by $36 \%$ (18 participants).

II stage - Interview.

The students of the two groups getting a bachelor's degree, having A2 and B2 level of English language knowledge, were asked to extend on the advantages and disadvantages of such emergency remote learning.

The results suggest that mostly they mentioned the same advantages as the ones specified in the questionnaire. The most frequently mentioned are 1) no need to spend money on travelling to the university; 2) such education is convenient and innovative; 3) you can't miss the lesson as it can be recorded or you can do online tasks later.

"You can be present at the lesson in any posture and clothes. You shouldn't spend money on fares and stationery."

"Teachers feel more comfortable at home preparing tasks with a cup of tea."

"You are at home and there is little chance that you will be late for your class."

"There are many tests for self-check."

As for the most frequent disadvantages, they are 1) problems with devices and internet connection; 2) lack of face to face communication; 3) many tasks and homework. However, the students added the following drawbacks: 1) the tasks are incorrectly 
formulated; 2) some teachers are bad at dealing with Information Technologies; 3) the platform Digital SUSU cannot bear big loads of data and many users.

"There is no face to face contact. You cannot be at the lessons all the time, because the Internet/light can be switched off."

"There is a greater amount of homework compared with traditional education."

"Incorrect operation of the platform, not very understandable interface, and sometimes there are difficulties with submission of your works."

"Some teachers and lecturers have poor IT skills and spend too much of lesson time on starting the learning process"

However, among both positive and negative points the students specified a great number of tests.

\section{DISCUSSION}

The pandemic situation of CoronaVirus 2020 (COVID19) has brought about many changes in the life of people, their education, and work. Schools and universities had to apply to emergency remote education for 3 months. It was viewed as distance education but the authors found many distinctive differences (Bozkurt, A., \& Sharma, R. C., 2020).

However, taking into account the possibility of repetition of the situation in the coming autumn it is necessary to make conclusions and observations of the experience and produce recommendations, which will facilitate and ease teaching and learning.

The observation of the outcome was conducted in the form of a questionnaire and interview. The students of the first, second, and third year participated in the experiment. The research was conducted based on the peculiarities of English language teaching in the National Research South Ural State University, where the platform Digital SUSU was used for delivering lessons, specified procedure regulation was created by Guidance department in the nearest possible time.

The main purpose of the questionnaire was to determine the preferable forms of online activities and other lesson specific characteristics. The advantages and disadvantages of such remote education were discussed in the questionnaire firstly and then uncovered in the interview with some representatives of the groups where the author conducted lessons.

Samperio, N. (2017) found out that listening is often considered to be the most "difficult skill to acquire", Buck (2001) mentions that "in the listening process students must use not only linguistic, but also non-linguistic sources of knowledge in order to interpret incoming data". Therefore, plus to the listening included in the student books specified in the academic programme, videos with tasks were added to the course on the platform Digital SUSU. 
The students found such tasks to be the most interesting as videos were both thematical and coincided with the topics of the lesson (it was mostly the case with the course for masters) and parts of films or short cartoons. Samperio, N. (2017) suggests that the reason "why students might prefer listening activities is that they seem to assess their listening skill based on their development in real life situations, mainly through Radio and TV, in which they are able or unable to comprehend natural spoken English delivered at normal speed". However, the students found them the least useful in what concerns language acquisition.

Vocabulary check-ups were a very frequent form of interactive tests as the situation with remote learning deprived them of the opportunity to check how students mastered active vocabulary. Therefore, such tasks were included into every lesson as a part of a control measure and as a necessary condition for obtaining credit for the course. The students found vocabulary practise tasks both interesting and useful.

Like in the literature, where grammar activities were also found within students' preferences Samperio, N. (2017), Peacock (1998), Schulz's (1996), Richards and Rodgers (2001), in our research the student mentioned grammar as both useful and interesting task. Samperio, N. (2017) argues that "commonly, learners believe that to be able to be proficient in English, it is necessary to learn the correct use of grammar despite what the communicative approaches suggest".

Although the students considered reading rather useful for mastering the language, it turned out to be of little interest to them. Basically, reading was not so amply used in the courses on the Digital SUSU platform as there are usually enough reading practice in paper student books. However, the students whose course involved Mock IELTS as a credit or exam task had to read more texts with the tasks to follow.

Writing, which is both very demanding in what concerns skills needed for it and the amount of additional time it consumes, was not very popular with the students. Moreover, the students tend to consider it not very useful as well. Here the problem may be in the way it is presented in the course as a task. Be it not so extensive or, perhaps, more entertaining (write a short blog; write the beginning of the story so that the other students could continue it; comment on the famous quotation and so on), the student might like it more. After the research, it becomes clear that this task needs close attention as it is very important for the students who prepare for international exams.

Although some students prefer doing tasks when it is convenient for them (it is quite possible, as the task are open for them and if they miss the lesson for some reasons, they can do the task later and get a score), the majority prefer to keep to the timetable.

Although the students called the lack of communication and face to face communication as a disadvantage, the most preferable form of lesson is BBB without a camera. It does not require any special installation package which can contain a virus or require special IT knowledge. You should not create an account as all the students get a login and a password to it when they enter the University. Moreover, BBB allows the users to enter it in the regime of only listening. So, you can have little technical means available and 
still be present at the lesson. However, from the experience, it is quite frustrating to conduct the lesson and have the feeling of communicating with the computer.

\section{CONCLUSION}

After carefully considering all the points specified by the students and taking into account the advantages and disadvantages mentioned, the following conclusions can be made.

The pandemic of Corona Virus 2020 (COVID19) has brought about many changes in everyday, academic, and financial life of people. However, prominent universities all over the world and in Russia had the opportunity to test its technical and methodological possibilities to survive and maintain the achieved level of professional, academic, and educational skills. In particular, the National Research South Ural State University, which has been actively applying its technical facilities for 10 years since the implementation of the platform Digital SUSU, had the chance to check its performance in this perspective and to facilitate any changes if some faults in its operations or missing parts are detected.

The research was conducted based on the English language course and the questionnaire and interview in which 50 students of the 1,2 and $3 \mathrm{~d}$ years of bachelor's degree and $1^{\text {st }}$ year of master's degree. The courses included general, business and professional aspects of the English language.

The main purpose of the research was to distinguish which tasks of the ones allocated on the platform Digital SUSU were most interesting and most useful for the students according to their opinion. What form of distance education they prefer as well as the study time they choose. What advantages and disadvantages of the suggested ones they agree with (the questionnaire). Some students were interviewed to develop the idea of the advantages and disadvantages of emergency remote learning (the interview).

Among the most interesting tasks, the students chose video tasks and vocabulary, whereas the most useful are grammar, vocabulary, and reading tasks.

The preferable form of studying was BigBlueButton on the platform Digital SUSU customized for South Ural State University needs and requirements. However, because of the technical problems some students encountered, other resources such as Discord and Google Meet were also chosen as favoured forms. The students still preferred more to study during the lesson time and according to the timetable.

The major advantage of remote learning is the ability to study from home, which was extended in the interview to the absence of the necessity to spend money on travelling to the university and on stationary.

There were not distinguished any "leaders" among disadvantages as technical requirements, no face to face contact, lack of communication, too much individual work and too many written tasks had an equal distribution of preferences. In the interview students also added that some teachers had little IT skills. 
However, in spite of all the difficulties experienced both by the students and the teacher, the semester ended with no significant difficulties, all the topics specified by the academic programme were covered, the students could pass their credits and exams in a remote format as well.

Future research should be conducted with the aim to improve existing courses as the situation with COVID19 showed the necessity of emergency remote teaching, which should not appear an obstacle in the knowledge acquisition process.

\section{REFERENCES}

Alekseev, V.M., Ilchenko, S.V. (2016). Peculiarities of contemporary distance education of contact managers. Actual problems of humanities and sciences, 9(1), 168171

Almosa, A. (2002). Use of Computer in Education, (2nd ed), Riyadh: Future Education Library.

Bollag, B., \& Overland M.A. (2001). Developing countries turn to distance education. Chronicle of Higher Education, 47(40), 29-31.

Bozkurt, A., \& Sharma, R. C. (2020). Emergency remote teaching in a time of global crisis due to Coronavirus pandemic. Asian Journal of Distance Education, 15(1), i-vi. https://doi.org/10.5281/zenodo.3778083

Brown, S. \& McIntyre, D. (1993). Making sense of teaching. Buckingham, England: Open University

Buck, G. (2001). Assessing listening. Cambridge, UK: Cambridge University Press.

Burdman, P. (1998). Cyber U. Anaheim (California) Orange County Register, September 13, sec. 1, p. 9

Dowling, C., Godfrey, J. M. \& Gyles N. (2003). "Do Hybrid Flexible Delivery Teaching Methods Improve Accounting Students' Learning Outcomes," Accounting Education:An International Journal, 12(4), 373-391.

Despotović-Zrakić, M., Marković, A., Bogdanović, Z., Barać, D., \& Krčo, S. (2012). Providing Adaptivity in Moodle LMS Courses. Educational Technology \& Society, 15(1), 326-338.

Dibiase, D. (2000). Is distance education a Faustian bargain? Journal of Geography in Higher Education, 24(1), 130-

Govaerts, S., Verbert, K., Klerkx, J., \& Duval, E. (2010). Visualizing activities for selfreflection and awareness. Lecture Notes in Computer Science, 6483, 91-100.

Hismanoglu, M. (2012). Prospective EFL Teachers' Perceptions of ICT Integration: A Study of Distance Higher Education in Turkey. Educational Technology \& Society, 15(1), 185-196. 
Laszlo, A., \& Castro, K. (1995). Technology and values: Interactive learning environments for future generations. Educational Technology, 35(2), 7-13.

Moore, M. G. (1989). Editorial: Three types of interaction. American Journal of Distance Education, 3(2), 1-7. https://doi.org/10.1080/08923648909526659

Peacock, M. (1998). Exploring the gap between teachers' and learners' beliefs about 'useful' activities for EFL. International Journal of Applied Linguistics, 8(2), 233-250.

Palloff, R. M., \& Pratt, K. (2013). Lessons from the virtual classroom: The realities of online teaching (2nd ed.). San Francisco, CA: Jossey-Bass.

Richards,J.C. (n.d.). Difference between task, exercise, activity. Retrieved from http://www.professorjackrichards.com/difference-task-exerciseactivity/

Romero, C., Ventura S., García E., et. al. (2008). Data mining in course management systems: Moodle case study and tutorial. Computers \& Education, 51 (1), 368-384.

Samperio Sanchez, Nahum. (2017). Discovering Students' Preference for Classroom Activities and Teachers' Frequency of Activity Use. Colombian Applied Linguistics Journal, 19(1), 51-66. https://dx.doi.org/10.14483/calj.v19n1.9292

Schulz, R. A. (1996). Focus on form in the foreign language classroom: Students' and teachers' views on error correction and the role of grammar. Foreign Language Annals, 29(3), 343-364.

Turoff, M., \& Hiltz, S. (1986). Remote learning: Technologies \& opportunities. Paper presented at the World Conference on Continuing Engineering Education (p. 3-12). https://files.eric.ed.gov/fulltext/ED332656.pdf

UNESCO (2020a). COVID-19 education response. https://en.unesco.org/covid19/educationresponse/globalcoalition

UNESCO (2020b). COVID-19 Educational disruption and response. https://en.unesco.org/covid19/educationresponse

UNESCO (2020c). Global education coalition. https://en.unesco.org/covid19/educationresponse/globalcoalition

UNESCO (2020d). National learning platforms and tools. https://en.unesco.org/covid19/educationresponse/nationalresponses\#WESTERN\%20EU ROPE\%20\&\%20NORTH\%20AMERICA

UNESCO (2020). Distance learning solutions. https://en.unesco.org/covid19/educationresponse/solutions

UNESCO (2020f). Startling digital divides in distance learning emerge. https://en.unesco.org/news/startling-digital-divides-distance-learning-emerge

Yang, N. \& Arjomand, L. H. (1999). "Opportunities and Challenges in ComputerMediated Business Education: An Exploratory Investigation of Online Programs," Academy of EducationalLeadership Journal, 3(2), 17-29. 


\section{APPENDIX A}

Here you can see the examples of the tasks on the platform Digital SUSU of the National Research South Ural State University.

\section{Video task}

Figure 1 shows an example of the task for the first-year students of master's degree. The students were to watch the video on beverages and to do the task on the video. Here we can see an example of drag and drop task.

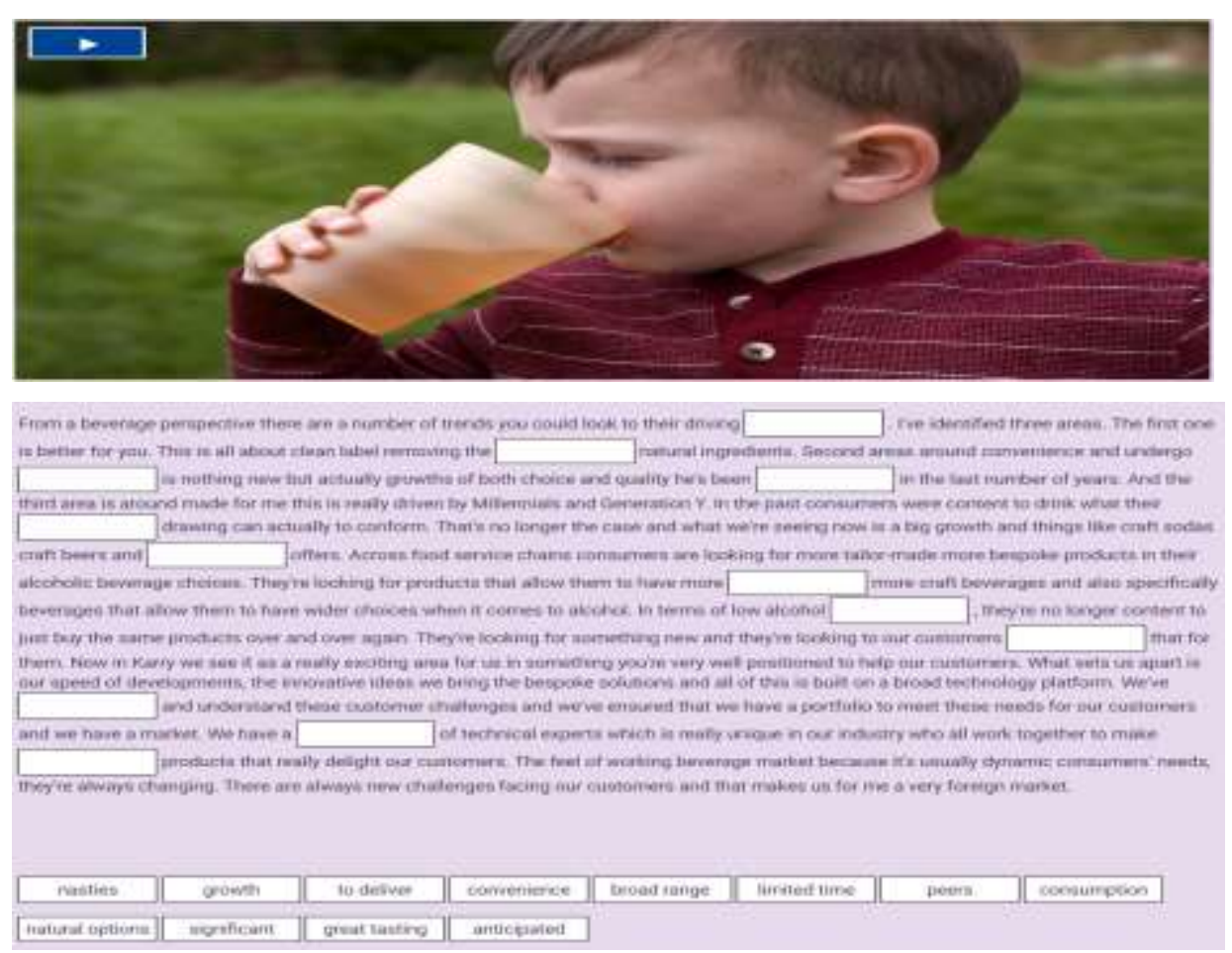

Figure 1

Video with tasks from the course for the first-year students of the master's degree.

\section{Grammar task}

Figure 2 presents an example of the task on grammar. The task was to choose from the variants suggested. 


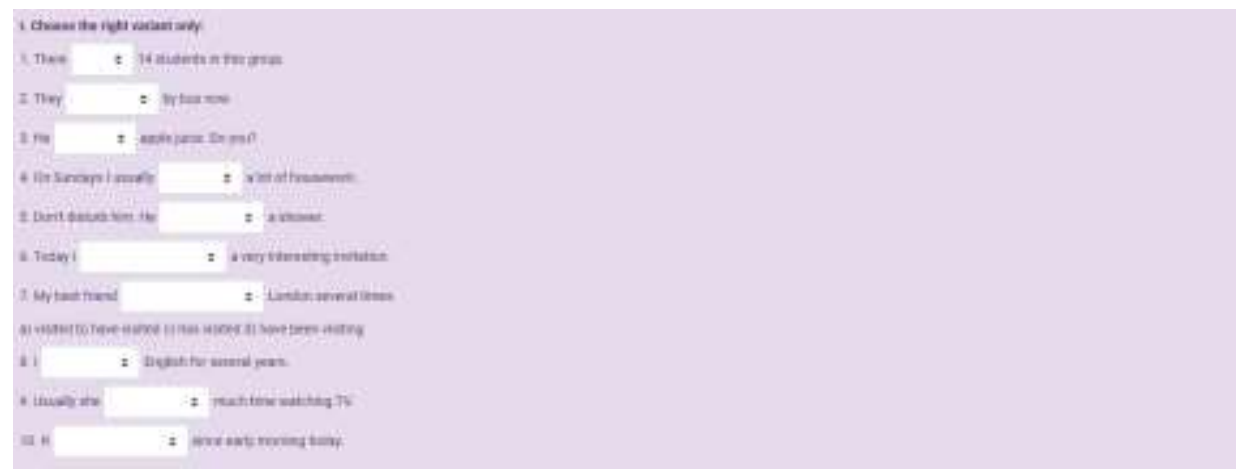

Figure 2

Grammar task from the course for first-year students of bachelor's degree.

\section{Vocabulary task}

Figure 3 presents an example of the task on vocabulary. The task was to choose the translation of the active vocabulary from the variants suggested.

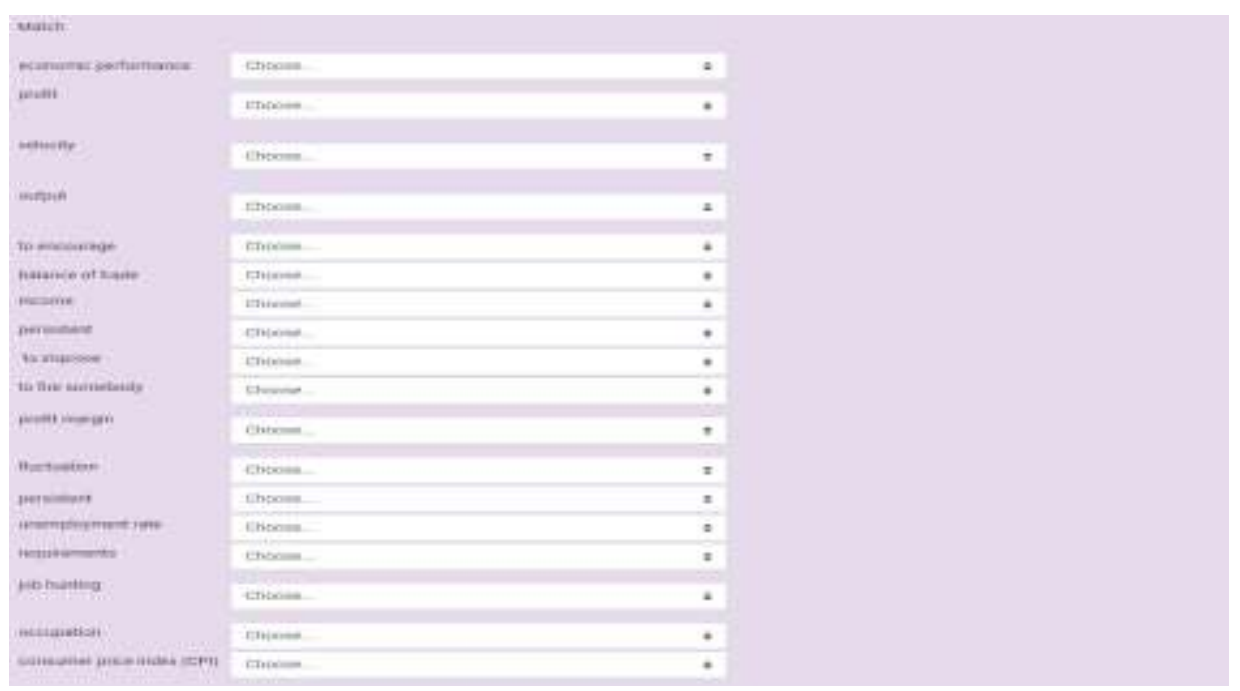




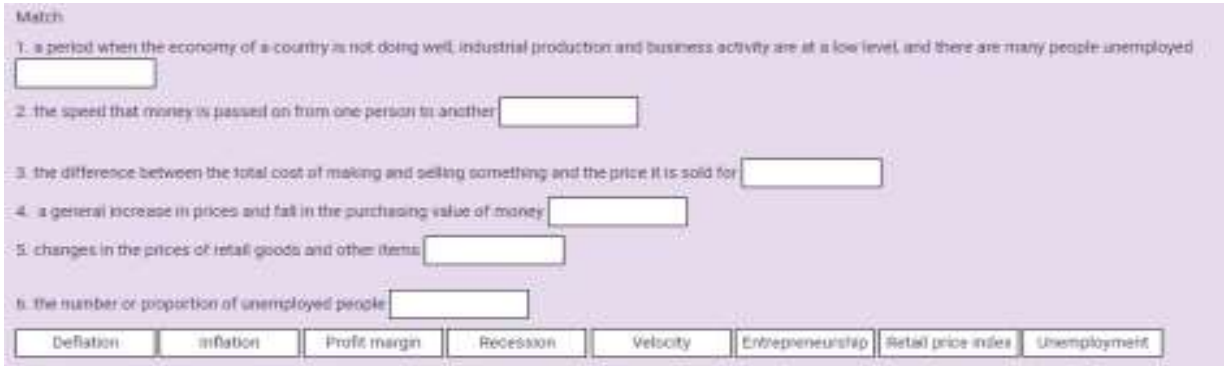

Figure 3

Vocabulary task from the course for first-year students of bachelor's degree.

\section{Reading task}

Figure 4 presents an example of the task on reading. The task was to choose the translation of the active vocabulary from the variants suggested.

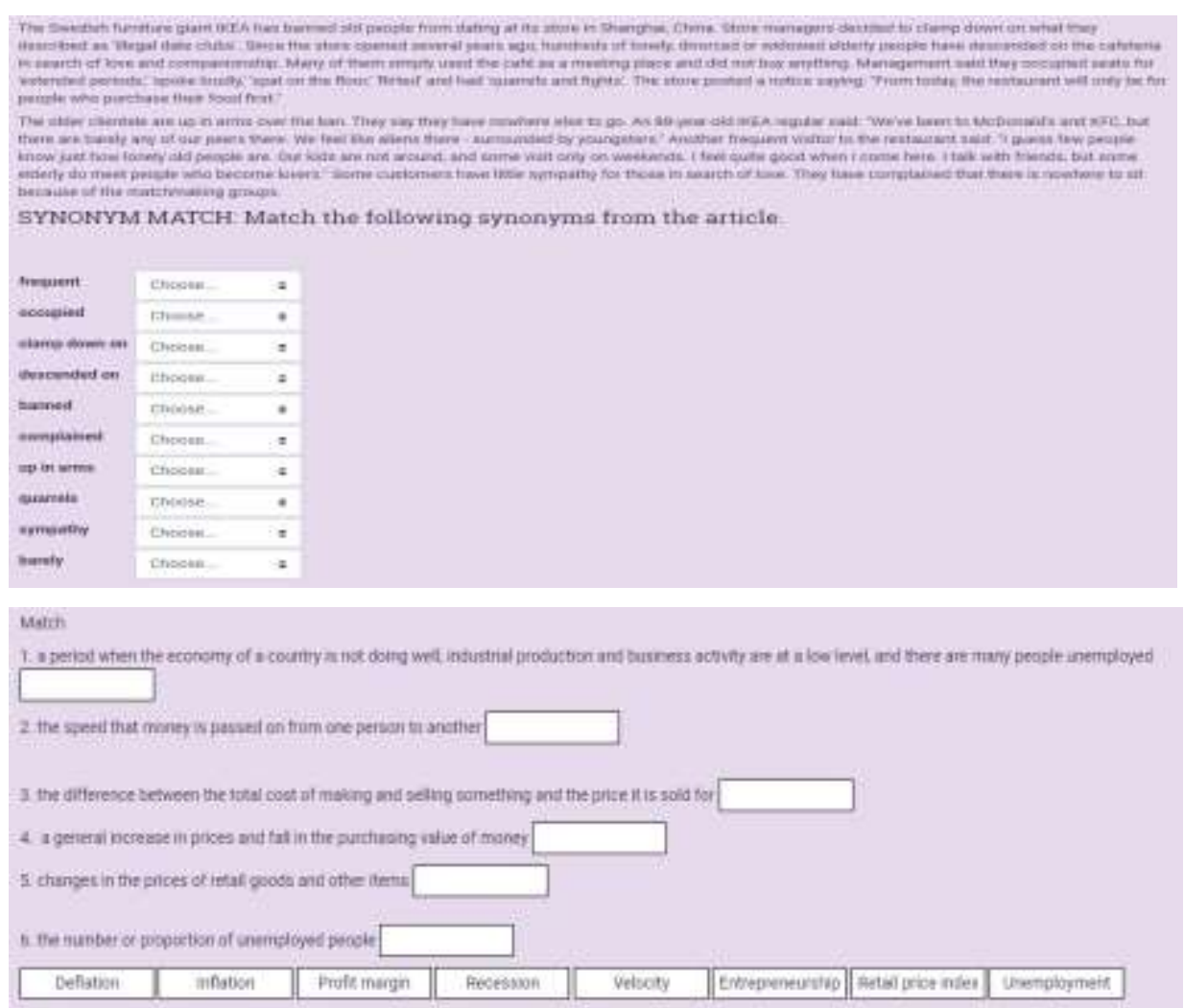

Figure 4

Reading task from the course for second-year students of bachelor's degree. 


\section{Writing task}

Figure 5 presents an example of the writing task. The task was to write an essay on the suggested topic according to the rules and requirements for IELTs exam.

You should spend about 40 minutes on this task.

Write about the following topic:

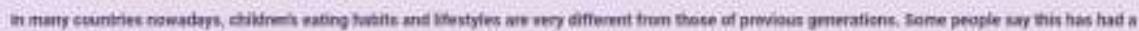

negative eftoct on their hasth

To shtal estern do you nome:

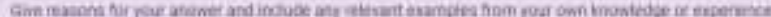

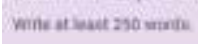

I. B $I$ I E E i o t is in

Figure 5

Writing task from the course for first-year students of bachelor's degree. 